\title{
Taura syndrome virus loads in Litopenaeus vannamei hemolymph following infection are related to differential mortality
}

\author{
Zhiming Cao"${ }^{1}$, Shiao Y. Wang ${ }^{1, *}$, Verlee Breeland ${ }^{2}$, Anne-Marie Moore ${ }^{2}$, \\ Jeffrey M. Lotz ${ }^{2}$ \\ ${ }^{1}$ Department of Biological Sciences, The University of Southern Mississippi, 118 College Dr. \# 5018, Hattiesburg, \\ Mississippi 39406, USA \\ ${ }^{2}$ Department of Coastal Sciences, Gulf Coast Research Laboratory, The University of Southern Mississippi, PO Box 7000, \\ Ocean Springs, Mississippi 39566, USA
}

\begin{abstract}
Taura syndrome is an economically important disease that can cause catastrophic losses of farmed shrimp. Without effective treatments for Taura syndrome virus (TSV), one approach to managing the problem is to selectively breed shrimp populations with increased disease resistance. To better understand why some shrimp can survive exposure to TSV, information is needed on how viral loads progress and persist following infection. Data reported here show that mortalities occurring mostly within $1 \mathrm{wk}$ of infection are associated with high viral titers, and titers as high as $10^{8.7}$ genome copies per $\mu \mathrm{l}$ hemolymph can persist for up to $3 \mathrm{wk}$ in survivors. Thereafter, and up to $\sim 9 \mathrm{wk}$ post-exposure, most surviving shrimp remain chronically infected with TSV loads ranging from $10^{4}$ to $10^{8}$ genome copies per $\mu \mathrm{l}$ hemolymph. Challenging shrimp from families with varying TSV resistance showed that in shrimp from less resistant families, the TSV load in hemolymph increased earlier and reached higher peaks than in shrimp from more resistant families. Although TSV loads in moribund shrimp from families differing in resistance did not differ significantly, infection loads among survivors were lower in shrimp from more resistant families. Taken together, the data suggest that lethal infection loads can occur in both more and less susceptible shrimp and that survivors represent shrimp in which viral expansion is better contained.
\end{abstract}

KEY WORDS: Taura syndrome virus $\cdot$ Litopenaeus vannamei $\cdot$ Shrimp $\cdot$ Virus Resale or republication not permitted without written consent of the publisher

\section{INTRODUCTION}

Taura syndrome (TS) is an economically important shrimp disease that was first described in Pacific white shrimp Litopenaeus vannamei cultured at farms near the mouth of the Taura River in Ecuador in 1992 (Jimenez 1992). As the disease was demonstrated to have viral etiology, the virus was named Taura syndrome virus (TSV) (Brock et al. 1995, Hasson et al. 1995). TSV is a small, icosahedral, non-enveloped virus containing a genome comprised of positivesense, single-stranded RNA (Bonami et al. 1997), and is classified within the family Dicistroviridae (Mari et al. 2002, Mayo \& Ball 2006) in the order Picornavirales (Le Gall et al. 2008).

TSV infects a number of penaeid shrimp species and can cause up to $95 \%$ mortality in farmed Litopenaeus vannamei (Brock et al. 1995). Following its initial discovery in 1992, TSV had spread to many shrimp farming regions, from South and Central America into North America by 1994 (Hasson et al. 1999a) and to SE Asia by 1998 (Tu et al. 1999, Yu \& Song 2000).

The course of a TSV infection in Litopenaeus vannamei progresses through several definable phases (Hasson et al. 1999b, Lotz et al. 2003). The prepatent asymptomatic phase occurs within the first 2 to $5 \mathrm{~d}$ 
following infection, in which the virus multiplies to levels sufficient to induce a symptomatic acute infection. The acute symptomatic phase lasts from 1 to $10 \mathrm{~d}$, during which elevated mortalities occur and shrimp display histological tissue lesions characteristic of TSV. Following the acute phase, when elevated mortalities cease, a chronic infection phase can arise where tissue lesions resolve and lymphoid organ spheroids develop. Chronic infection may persist throughout life.

In the absence of effective treatments to prevent TSV infection and disease, one approach is to selectively breed shrimp populations with increased disease resistance. Argue et al. (2002) and Moss et al. (2005) have reported successes in selective breeding for increased survival following exposure to TSV. Srisuvan et al. (2006) showed that TSV-resistant Litopenaeus vannamei were more resistant to developing TS lesions and had lower viral genome copy numbers compared to TSV-susceptible shrimp. However, little is known about the mechanisms that enhance shrimp survival (Flegel 2007).

To examine viral pathogenesis, determining the relationship between TS disease and infection load would help explain why some shrimp survive exposure to TSV. It is not known, for example, whether infection loads never reach lethal levels in shrimp able to survive TSV challenge or whether these shrimp are more tolerant of such high-level TSV infection loads.

Reported here are data tracking viral loads through the course of TSV infections in Litopenaeus vannamei to better understand what infection load is required to induce disease and mortality. In 2 challenge trials, TSV abundance in hemolymph of infected shrimp was measured at regular intervals to examine the rate of virus expansion and its relative abundance in shrimp that either died or survived to become persistent carriers. In the first trial, the dynamics of TSV expansion were examined in a population of shrimp, and in the second trial, individual shrimp were examined. In a third trial, TSV loads in moribund and surviving shrimp were compared among families with varying resistance and differing survival following exposure to TSV.

\section{MATERIALS AND METHODS}

Shrimp and viral infection. Pacific white shrimp Litopenaeus vannamei 3 to $5 \mathrm{~g}$ in weight were used in the TSV infection studies. Shrimp from the Kona stock as well as families varying in TSV susceptibility (ranging from highly susceptible to highly resistant) were obtained from the Oceanic Institute in Hawaii (Argue et al. 2002, Moss et al. 2005). The TSV isolate used originated from Texas, USA, in 1995 and has been maintained in $L$. vannamei. At the beginning of all trials shrimp were exposed once per os to coarsely chopped cephalothoraces of TSV-infected shrimp at a rate of $3 \%$ of shrimp body weight. Prior to use, infected shrimp tissue was stored at $-80^{\circ} \mathrm{C}$. All challenges were conducted using $15 \mathrm{ppt}$ salinity seawater at $27^{\circ} \mathrm{C}$.

In the first trial, 500 shrimp (Kona stock) were placed into one $2.5 \mathrm{~m}$ diameter tank. After TSV exposure, hemolymph was collected daily from 10 randomly selected shrimp from Day 0 (prior to exposure) to Day 8. Beyond Day 8, hemolymph was sampled on Days $14,21,31,41,51$ and 61 . We stopped on Day 61 because there were insufficient shrimp to continue the trial. Sampling of hemolymph has been shown to be more reliable than sampling of pleopod for monitoring TSV loads by real-time quantitative reverse transcription-PCR (qRT-PCR) (Poulos et al. 2008). Shrimp that had been sampled were not returned to the tank.

In a second trial, TSV infection in individual shrimp was followed to determine whether the pattern in individual infections mirrored that of a population of shrimp. Five shrimp from 1 resistant family and 29 Kona shrimp (susceptible) were held individually in 21 containers and exposed to TSV. Over a $20 \mathrm{~d}$ period following TSV exposure, a sample of hemolymph was collected from each shrimp on Days 2, 5, 8, 11, 16 and 20 post-exposure for Kona stock or Days 3, 6, 9, 12, 16 and 20 post-exposure for resistant shrimp.

In the third trial, 248 shrimp from 65 families were placed in a $2.5 \mathrm{~m}$ diameter tank. After TSV exposure, shrimp were observed for $20 \mathrm{~d}$. Hemolymph was sampled from moribund shrimp and, on Day 20, from all surviving shrimp. In all 3 trials, hemolymph collected from shrimp not exposed to TSV served as negative controls.

Real-time qRT-PCR. PCR primers and a molecular beacon (MB) probe used in real-time qRT-PCR were designed using the TSV 822 cDNA sequence reported by $\mathrm{Lu}$ et al. (2004). The primers (406F and 217R) amplify a $217 \mathrm{bp}$ product. This PCR product was cloned and the plasmid was used as template to synthesize TSV RNA by in vitro transcription as described in 'Preparation of TSV synthetic RNA for real-time qRT-PCR'. The sequences of the $406 \mathrm{~F}$ and $217 \mathrm{R}$ primers are 5'-TAT TAC TAC AAC GAG CCC AG-3' and $5^{\prime}$-CTC ATT TTC CGT CCT TTC C-3', respectively. The sequence of the MB probe is 5'-FAM-CCA GCG TTT GAT ACT AAC CGT GCT ATG CGC TGGDAB CYL-3'. The underlined nucleotides form the stem sequence with the loop region complementing a 21 nucleotide stretch in the TSV genome.

RNA extraction. For qRT-PCR, total nucleic acid was extracted from $10 \mu \mathrm{l}$ shrimp hemolymph using Proteinase $\mathrm{K}$ digestion followed by phenol extraction. Briefly, the hemolymph was mixed with $100 \mu \mathrm{l}$ Proteinase $\mathrm{K}$ digestion solution $(50 \mathrm{mM}$ Tris- $\mathrm{HCl}$, $\mathrm{pH}$ 8.0, 
$0.5 \%$ sodium dodecyl sulfate and $0.2 \mathrm{mg} \mathrm{ml}^{-1}$ Proteinase $\mathrm{K}$ ) and incubated at $60^{\circ} \mathrm{C}$ for $1 \mathrm{~h}$. After cooling on ice, the sample was extracted with an equal volume of phenol:chloroform:isoamyl alcohol (25:24:1, pH 5.2), followed by an extraction with chloroform. Total nucleic acid was precipitated by adding 2.5 volumes of $95 \%$ ethanol and storage at $-20^{\circ} \mathrm{C}$ for $1.5 \mathrm{~h}$. Polyacryl Carrier ( $3 \mu \mathrm{l}$ ) (Molecular Research Center) was added to aid nucleic acid recovery. After centrifugation $(12000 \times g$ for $10 \mathrm{~min})$, the pellet was washed once with $75 \%$ ethanol, air-dried and dissolved in $40 \mu \mathrm{l}$ diethylpyrocarbonate-treated water.

The efficiency and consistency of the nucleic acid extraction procedure was tested by extracting 5 aliquots of hemolymph from the same infected shrimp. The coefficient of variation (CV) of the TSV copies obtained using the real-time PCR assay performed on the 5 extracts was $19.9 \%$.

Real-time RT-PCR. To synthesize first-strand cDNA, $2 \mu \mathrm{l}$ of the $20 \mu \mathrm{l}$ nucleic acid extract was incubated at $37^{\circ} \mathrm{C}$ for $60 \mathrm{~min}$ in a $10 \mu \mathrm{l}$ reaction containing Moloney Murine Leukemia Virus (M-MLV) reverse transcriptase buffer, $500 \mathrm{nM} 101 \mathrm{~F}$ and $101 \mathrm{R}$ primers, $1 \mathrm{mM}$ dNTPs, $100 \mathrm{U}$ M-MLV reverse transcriptase and $10 \mathrm{U}$ RNasin RNase inhibitor (Promega). The reaction was then heated at $95^{\circ} \mathrm{C}$ for $5 \mathrm{~min}$ before use as template for PCR.

Each PCR used $5 \mu \mathrm{l}$ cDNA in a $25 \mu \mathrm{l}$ reaction. The reaction mixture contained $1 \times$ Promega Taq polymerase buffer A $(50 \mathrm{mM} \mathrm{KCl}, 10 \mathrm{mM}$ Tris- $\mathrm{HCl}, \mathrm{pH} 9.0$ at $25^{\circ} \mathrm{C}, 1.5 \mathrm{mM} \mathrm{MgCl}_{2}$ and $1 \%$ Triton X-100), $200 \mu \mathrm{M}$ dNTPs, additional $\mathrm{MgCl}_{2}$ to bring the final concentration to $3.5 \mathrm{mM}, 0.2 \mathrm{uM} 101 \mathrm{~F}$ and $101 \mathrm{R}$ primers, $0.2 \mu \mathrm{M}$ MB probe, $1 \times$ PCR Additive Reagent (PAR) and $2.5 \mathrm{U}$ Taq polymerase (Promega). PAR at $1 \times$ contains $1.7 \mathrm{mM}$ Tris- $\mathrm{HCl}, \mathrm{pH} 8.0,0.2 \mathrm{mg} \mathrm{ml}^{-1}$ non-acetylated BSA, $150 \mathrm{mM}$ trehalose and $0.2 \%$ Tween-20. Thermal cycling conditions included an initial denaturation at $95^{\circ} \mathrm{C}$ for $150 \mathrm{~s}$, followed by 35 cycles of amplification using $95^{\circ} \mathrm{C}$ for $15 \mathrm{~s}, 53^{\circ} \mathrm{C}$ for $30 \mathrm{~s}$ and $72^{\circ} \mathrm{C}$ for $30 \mathrm{~s}$.

Preparation of TSV synthetic RNA for real-time qRT-PCR. TSV RNA in shrimp hemolymph was quantified by comparing the threshold cycle $\left(C_{\mathrm{T}}\right)$ value of samples against a standard curve generated using a dilution series of in vitro transcribed TSV RNA. The RNA was prepared from a plasmid containing a $217 \mathrm{bp}$ product amplified by RT-PCR using the primers $406 \mathrm{~F}$ and $217 \mathrm{R}$ and cloned into pT7blue (Novagen).

Briefly, pTSV DNA was linearized with Sma I (New England Biolabs), run in a $1 \%$ agarose gel, and the linear DNA was purified using a Zymoclean Gel DNA Recovery Kit (Zymo Research). RNA was synthesized using this gel-purified linear pTSV DNA and a DuraScribe T7 Transcription Kit (Epicenter). The reaction was incubated at $37^{\circ} \mathrm{C}$ for $6 \mathrm{~h}$, and template DNA was removed by digestion with 2 U RNase-free DNase I at $37^{\circ} \mathrm{C}$ for $30 \mathrm{~min}$. The sample was extracted with phenol-chloroform, and the synthetic RNA was concentrated using ammonium acetate precipitation. Only full-length RNA, gel purified from a 5.5\% denaturing polyacrylamide gel, was used for qRT-PCR. Purified full-length TSV synthetic RNA was quantified using the RiboGreen RNA Quantitation Kit (Invitrogen). Serial 10-fold dilutions of TSV standard were made using $1 \times$ PAR as diluent and stored at $-80^{\circ} \mathrm{C}$.

The linearity, range, reproducibility and reliability of qRT-PCR were tested using both the TSV synthetic RNA standards as well as RNA extracted from TSVinfected shrimp. The qRT-PCR was found to be quantitative over at least 7 orders of magnitude from $2 \times 10^{3}$ to $2 \times 10^{9}$ TSV RNA copies (data not shown). Reproducibility was tested using multiple aliquots of serial 10 -fold dilutions of the synthetic RNA. Four aliquots of each dilution were tested in 1 test (intra-assay) and in 4 separate tests (inter-assay). The $\mathrm{CV}$ for the $C_{\mathrm{T}}$ values obtained varied between 0.20 and $2.01 \%$ for the intraassay and between 1.27 and $2.61 \%$ for the inter-assay. Using RNA extracted from hemolymph of 3 TSVinfected shrimp and assayed 4 times, the CV was $3.26 \%$.

qRT-PCR assay optimization. The use of Proteinase K digestion and acidic phenol extraction provided a simple, quick and cost-effective method to isolate TSV RNA from shrimp hemolymph for qRT-PCR. However, it was observed during initial assay development that samples likely to be TSV-positive occasionally failed to produce fluorescence. Diluting these samples 10- or 100-fold with water yielded fluorescence, suggesting that they contained PCR inhibitors.

To address this, hemolymph RNA extracted from 24 healthy shrimp was tested for the presence of inhibitors. The RNA was added to real-time PCRs containing cloned TSV plasmid cDNA. Among the 24 samples, 7 contained an unknown inhibitor that reduced PCR amplification efficiency. Using different amounts of each of these 7 samples in real-time qRTPCRs containing a standard amount of TSV synthetic RNA $\left(2 \times 10^{8}\right.$ RNA copies per reaction), it was determined that diluting the extracted RNA to correspond to $0.05 \mu \mathrm{l}$ shrimp hemolymph resulted in avoidance of PCR inhibition (Table 1). The $C_{\mathrm{T}}$ value obtained with the TSV RNA control alone was 13.1, and the $C_{\mathrm{T}}$ values with synthetic RNA in the presence of RNA from $0.05 \mu \mathrm{l}$ shrimp hemolymph varied within 0.5 of 13.1 for all 7 samples. Adding RNA extracted from more than $0.05 \mu l$ hemolymph inhibited some of the tests. Therefore, subsequent qRT-PCR tests to quantify TSV RNA in shrimp hemolymph used an amount of extracted RNA equivalent to $0.05 \mu$ shrimp hemolymph. 
Table 1. Real-time qRT-PCR to determine hemolymph volumes that avoid the effects of PCR inhibitors. (-): qRT-PCR did not generate a threshold cycle $\left(C_{\mathrm{T}}\right)$ value

\begin{tabular}{|lcccc|}
\hline \multirow{2}{*}{$\begin{array}{l}\text { Hemolymph } \\
\text { sample }\end{array}$} & $\begin{array}{c}0.75 \mu \mathrm{l} \\
\text { hemolymph }\end{array}$ & $\begin{array}{c}0.25 \mu \mathrm{l} \\
\text { hemolymph }\end{array}$ & $\begin{array}{c}0.1 \mu \mathrm{l} \\
\text { hemolymph }\end{array}$ & $\begin{array}{c}0.05 \mu \mathrm{l} \\
\text { hemolymph }\end{array}$ \\
\cline { 3 - 5 } 1 & 13.20 & 15.83 & 12.99 & 12.90 \\
2 & - & - & - & 13.23 \\
3 & - & 13.67 & 13.75 & 13.38 \\
4 & 13.43 & 13.46 & 13.17 & 13.45 \\
5 & - & - & 15.96 & 13.27 \\
6 & - & - & - & 13.59 \\
7 & - & - & - & 13.35 \\
RNA standard alone & 13.14 & 13.14 & 13.14 & 13.14 \\
\hline
\end{tabular}

TSV-infected tissue (Fig. 1). High mortality occurred between Days 3 and 7 , with a peak of 68 shrimp dying on Day 5. Mortality declined rapidly thereafter, with no deaths occurring beyond Day 13. Of the 500 shrimp, 134 $(26.8 \%)$ remained alive at the end of the trial on Day 61. No mortality occurred among the control shrimp and no hemolymph samples collected from these shrimp were positive for TSV.

TSV was first detected by real-time qRT-PCR prior to mortalities at $24 \mathrm{~h}$ post-exposure in 7 of 10 shrimp sampled (Fig. 2). The mean TSV RNA copy load increased from $10^{4.4}$ to $10^{7.4}$ per

The addition of the PCR enhancer PAR was also important for avoiding the effects of PCR inhibitors. The decision to use extracted RNA equivalent to $0.05 \mu \mathrm{l}$ shrimp hemolymph was based on data obtained using PAR. When PAR was omitted, PCR was inhibited with 3 of the 7 test samples. With one of the 4 samples for which fluorescence was obtained, the $C_{\mathrm{T}}$ value increased by over 2.5 (Table 2).

Statistical analysis. Shrimp TSV RNA loads from the third trial were compared statistically using a 2-way ANOVA with survival (whether shrimp survived or died) and tolerance (TSV survival history of the shrimp family) as covariates. Analysis was performed using $\log _{10}$-transformed data and pairwise comparisons were made with p-value adjustment for multiple comparisons.

\section{RESULTS}

In the first trial to track changes in TSV infection loads over time in hemolymph during a population exposure, shrimp mortalities began $2 \mathrm{~d}$ after exposure to

Table 2. Effectiveness of the PCR Additive Reagent (PAR) in reducing PCR inhibition in real-time qRT-PCRs containing Litopenaeus vannamei shrimp hemolymph RNA. $(-)$ : qRT-PCR did not generate a threshold cycle $\left(C_{\mathrm{T}}\right)$ value

\begin{tabular}{lcc|}
\hline \multirow{2}{*}{$\begin{array}{l}\text { Hemolymph } \\
\text { sample }\end{array}$} & \multicolumn{2}{c|}{$C_{\mathrm{T}}$} \\
\cline { 2 - 3 } & With PAR in PCR & Without PAR in PCR \\
\hline 1 & 12.90 & 13.79 \\
2 & 13.23 & - \\
3 & 13.38 & 13.93 \\
4 & 13.45 & 13.43 \\
5 & 13.27 & - \\
6 & 13.59 & - \\
7 & 13.35 & 15.87 \\
RNA standard alone & 13.14 & 13.36 \\
\hline
\end{tabular}

$\mu l$ hemolymph from Day 1 to Day 2 and peaked on Day 4 at $10^{8.7}$ RNA copies per $\mu$ l hemolymph. The TSV load

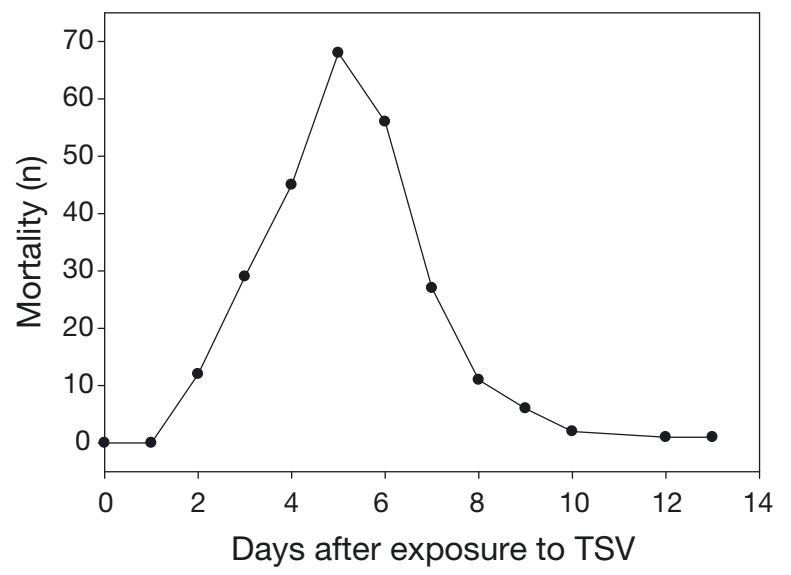

Fig. 1. Litopenaeus vannamei. Daily mortality of juvenile L. vannamei following per os exposure to Taura syndrome virus (TSV)-infected tissue. No. of shrimp $(n)=500$

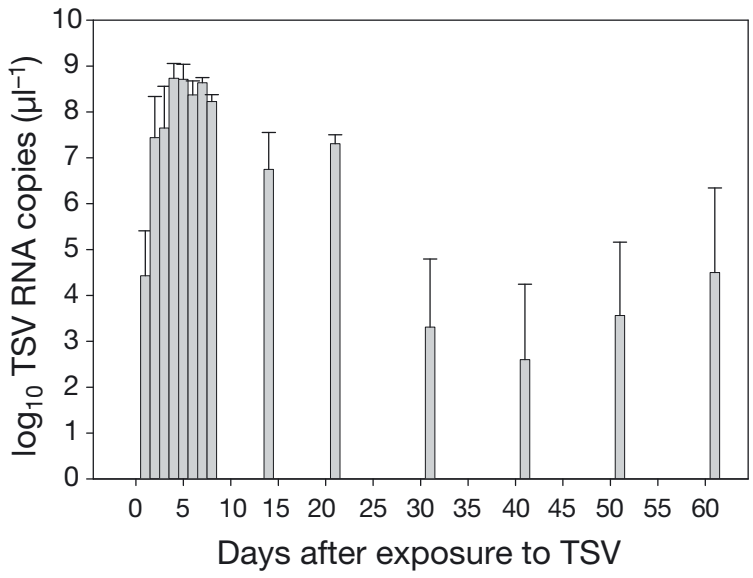

Fig. 2. Litopenaeus vannamei. Mean Taura syndrome virus (TSV) load in shrimp hemolymph over time determined by real-time qRT-PCR. Error bars are $\mathrm{SE}_{;} \mathrm{n}=10$ shrimp for Days 0-8, 14 and 21; $\mathrm{n}=6$ shrimp after Day 21 
in shrimp remained high from Days 4 to 8 , ranging from $10^{8.2}$ to $10^{8.7}$ RNA copies per $\mu$ l hemolymph. Upon cessation of mortalities, TSV loads gradually declined, with mean loads among infected shrimp between Days 14 to 20 post-exposure dropping to $\sim 10^{6}$ copies per $\mu l$ hemolymph. By Day 31 post-exposure, the viral load had further declined to $\sim 10^{3}$ to $10^{4}$ RNA copies per $\mu \mathrm{l}$ hemolymph and remained at this level until the end of the trial. There was, however, considerable variation in TSV load among the surviving shrimp during this period, and no TSV RNA was detected in 4, 3 and 2 of 6 shrimp sampled on Days 41, 51 and 61, respectively. In contrast, TSV loads ranging between $10^{4}$ and $10^{8}$ copies per $\mu \mathrm{l}$ hemolymph were detected in the other shrimp.

In the second trial, in which TSV loads were tracked over time in individual shrimp, all resistant shrimp survived to Day 20, whilst only 9 of 29 (31\%) of the susceptible Kona shrimp survived. Among surviving shrimp, the TSV load in Kona shrimp increased earlier and reached higher peaks than in the resistant shrimp (Fig. 3). Kona shrimp exhibited a mean peak load of $10^{6.01}$ RNA copies per $\mu$ hemolymph on Day 8, whereas in the resistant shrimp, the mean peak load was only $10^{2.18}$ and was not reached until Day 20. TSV RNA loads in both were lower than mean loads detected in moribund shrimp (Fig. 4). No negative control shrimp died and no TSV was detected in any of their hemolymph samples.

In the third trial, which compared TSV loads in moribund shrimp with survivors from families of varying TSV resistance, 159 (64.1\%) shrimp died and 89 remained alive (35.9\% survival) by Day 21 . The mean load detected among moribund shrimp was $10^{8.77}$ RNA copies per $\mu$ l hemolymph, whereas the load was 1000-

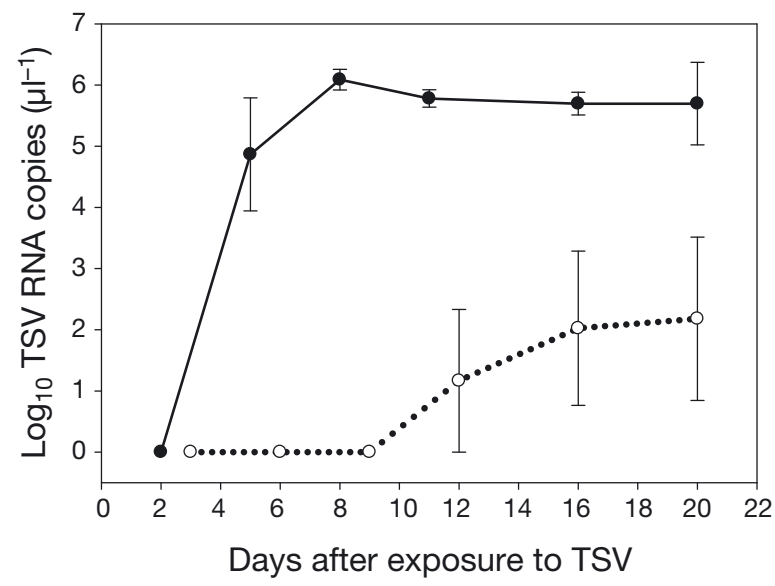

Fig. 3. Litopenaeus vannamei. Taura syndrome virus (TSV) RNA copy numbers in hemolymph of individual L. vannamei that survived acute infection. $\bullet$, solid line: Kona susceptible stock, $\mathrm{n}=9 ; \mathrm{O}$, dotted line: resistant stock, $\mathrm{n}=5$. Error bars are SE

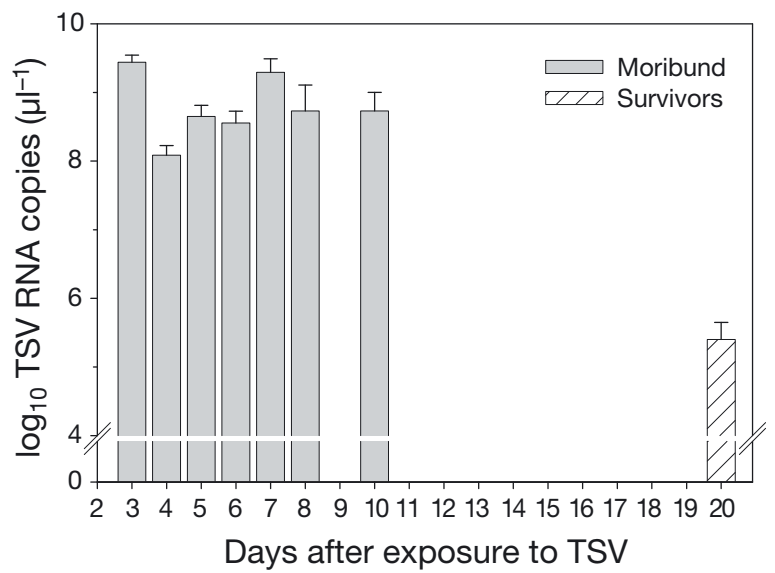

Fig. 4. Litopenaeus vannamei. Mean Taura syndrome virus (TSV) RNA copy numbers in moribund and surviving shrimp following infection with TSV. Error bars are SE; $\mathrm{n}=248$ shrimp (159 moribund and 89 survivors)

fold lower $\left(10^{5.77}\right.$ copies $\left.\mu \mathrm{l}^{-1}\right)$ among the survivors at Day 20 post-exposure (Fig. 4). No negative control shrimp died nor were any negative control hemolymph samples positive for TSV.

Based on family survival histories following exposure to TSV, shrimp were divided into Group 1 families with low survival ( 0 to $25 \%$ ), Group 2 families with survival from 25 to $50 \%$ and Group 3 families with survival above $50 \%$. Among the 159 moribund shrimp originating from 65 broodstock, mean TSV loads were not significantly different $(p=0.538)$ among shrimp from the 3 family groups (Fig. 5). The mean TSV loads for shrimp in Groups 1 to 3 were $10^{8.63}, 10^{8.85}$ and $10^{8.85}$ RNA copies per $\mu$ l of hemolymph, respectively.

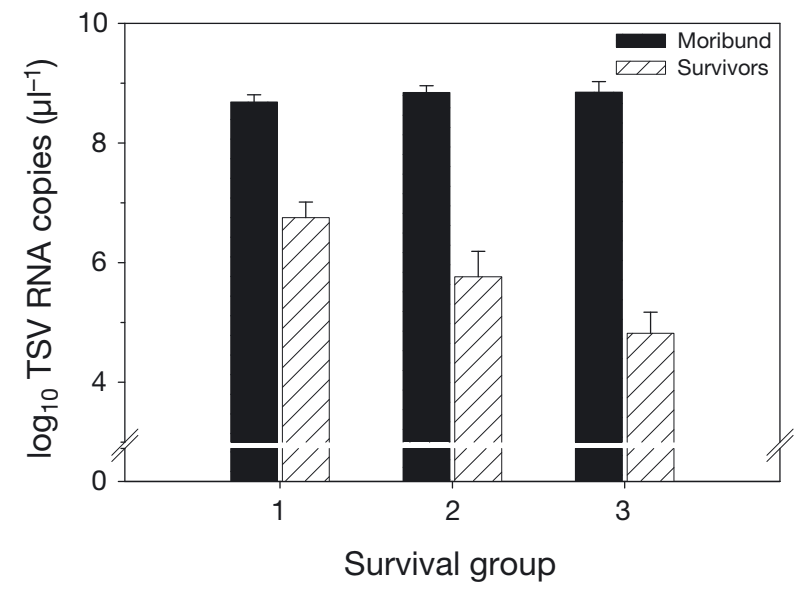

Fig. 5. Litopenaeus vannamei. Mean Taura syndrome virus (TSV) RNA copies among TSV-infected shrimp grouped according to their resistance to TSV and determined by realtime qRT-PCR. Group 1 comprised shrimp from families with low survival $(0-25 \%)$, Group 2 from families with medium survival $(>25-50 \%)$ and Group 3 from families with high survival $(>50 \%$ ). Error bars are $\mathrm{SE} ; \mathrm{n}=248$ shrimp (159 moribund and 89 survivors) 
In contrast, the TSV load in hemolymph of surviving shrimp varied inversely $(p<0.001)$ with survival among the 3 groups (Fig. 5). The mean loads of shrimp in Groups 1 to 3 were $10^{6.75}, 10^{5.76}$ and $10^{4.82}$ RNA copies per $\mu$ hemolymph, respectively. Moreover, the relationship of the survival and tolerance covariates to TSV infection loads was statistically significant $(\mathrm{p}=$ 0.006). It is also worthwhile noting that among the 10 surviving shrimp in which TSV could no longer be detected using real-time qRT-PCR, 0 belonged to Group 1, 1 belonged to Group 2 and 9 belonged to Group 3, the group with the highest resistance to TSV.

\section{DISCUSSION}

TS remains a problematic disease in shrimp aquaculture. In parallel with the need to breed shrimp populations with increased disease resistance, there is a need to better understand the mechanism of resistance. The present study focused on changes in viral load during disease progression. In the first population trial, results show that the TSV load in shrimp hemolymph following exposure to TSV-infected shrimp tissue was high $\left(10^{7}\right.$ to $10^{8}$ RNA copies per ul hemolymph) during the first $8 \mathrm{~d}$ of the infection and low $\left(10^{3}\right.$ to $10^{4}$ RNA copies per ul hemolymph) thereafter. Most mortality (66\%) occurred in the $3 \mathrm{~d}$ period between Days 4 and 6. This mortality/survival pattern corresponds well with previous studies of TSV infection and pathogenesis in Litopenaeus vannamei (Hasson et al. 1999b) and confirms that higher viral loads correspond with elevated mortality and acute histological lesions, while lower loads correspond with reduced pathology, resolving lesions and chronic infections. The prolonged chronic phase documented in the present study and the study by Hasson et al. (1999c) has important implications for shrimp aquaculture. Although TSV-induced mortalities cease after the initial acute infection phase and cuticular lesions resolve, shrimp can remain carriers for prolonged periods. In this respect, TSV is similar to white spot syndrome virus, yellow head virus and other viruses which can also be carried in subclinical states at low infection loads (Tsai et al. 1999) but are the source of disease outbreaks when shrimp become stressed by culture conditions (Lotz et al. 2005).

However, the TSV load pattern observed in the population study (high load during the acute phase followed by a reduced load during the chronic phase) gave no real insight into how TSV loads change over time among individuals in relation to survival. As moribund shrimp in the acute infection phase are removed, drops in TSV load observed subsequently might have simply reflected the loss of heavily infected shrimp from the population. It is possible that survivors are able to better tolerate and clear high TSV loads and make the transition from the acute to chronic infection phases. It is also possible that survivors are better at resisting high TSV loads during the acute phase of infection. Additional trials were conducted to address these 2 possibilities.

In a second challenge trial, TSV loads in individual shrimp destined to survive displayed a somewhat different pattern to that evident from examining a shrimp population. Individuals that survived possessed lower peak TSV loads followed by subsequent slow declines. Interestingly, the mean peak loads of individuals that survived were considerably lower than those detected in moribund shrimp that succumbed to the disease. Moreover, shrimp from the most resistant family had lower peak TSV loads that occurred later than individuals from more susceptible families, even when they were destined to survive. It appears from these data that shrimp survive TSV infection not by better accommodating high loads and subsequently reducing them, but rather by limiting TSV proliferation and maintaining lower overall infection levels than more susceptible shrimp.

In a third challenge trial, the mechanism of TSV resistance was further examined using Litopenaeus vannamei selectively bred for resistance to TSV. Of particular interest were differences in viral loads among shrimp from families varying in resistance, both in moribund shrimp and in shrimp that survived infection. There was no significant difference in viral loads in moribund shrimp destined to die among individuals in the 3 resistance groups. Interestingly, however, mean TSV loads were noted to be the lowest in shrimp from families with higher resistance and vice versa. Taken together, these results suggest that the lethal viral load remains consistent among shrimp, whether TSV-susceptible or TSV-resistant. The factor that determines survival is the level, and perhaps duration, of viral expansion.

It is not known how some shrimp are able to better control TSV loads, but there is evidence that reduced viral expansion at least partially explains the mechanism of viral resistance, rather than resistance being due to shrimp tolerating higher loads. Srisuvan et al. (2006) also observed an inverse relationship between survival and viral loads in shrimp exposed to TSV. They compared TSV-resistant to TSV-susceptible Litopenaeus vannamei and found that resistant shrimp had significantly lower TSV loads and higher survival probabilities when challenged with 3 of 4 TSV variants. Further research is needed to better understand factors that limit viral expansion. Interestingly, Stuck et al. (1996) reported in a study of Baculovirus penaei that infection rates were higher in larval and postlarval shrimp with higher levels of lipid energy reserve. The observation that shrimp in better nutritional condition 
were more susceptible to viral infection supports a resource limitation hypothesis. Resources that limit viral expansion, such as the number or nutritional status of susceptible cells, may play a role in viral resistance. In addition, shrimp bred to be more resistant to TSV might possess tissues with fewer cell surface receptors or better lymphoid organ systems that can process spheroids more quickly to the terminal apoptotic morphotype (Type C; Hasson et al. 1999c), so that TSV-infected cells can be eliminated more quickly. Future research on mechanisms that limit viral expansion is needed to provide more detailed insight into this potential mechanism of viral resistance.

Acknowledgements. This study was funded by the United States Department of Agriculture, Cooperative State Research Education and Extension Service grant numbers 9838808-6019 and 2002-38808-01381.

\section{LITERATURE CITED}

Argue BJ, Arce SM, Lotz JM, Moss SM (2002) Selective breeding of Pacific white shrimp (Litopenaeus vannamei) for growth and resistance to Taura syndrome virus. Aquaculture 204:447-460

Bonami JR, Hasson KW, Lightner DV (1997) Taura syndrome of marine penaeid shrimp: characterization of the virus agent. J Gen Virol 78:313-319

Brock J, Gose R, Lightner D, Hasson K (1995) An overview on Taura syndrome, an important disease of farmed Penaeus vannamei. In: Browdy C, Hopkins J (eds) Swimming through troubled water. Proc Special Session on Shrimp Farming, Aquaculture '95 Feb 1-4, San Diego, CA. World Aquaculture Society, Baton Rouge, LA, p 84-94

Flegel TW (2007) Update on viral accommodation, a model for host-viral interaction in shrimp and other arthropods. Dev Comp Immunol 31:217-231

Hasson KW, Lightner DV, Poulos BT, Redman RM, White BL, Brock JA, Bonami JR (1995) Taura syndrome in Penaeus vannamei: demonstration of a viral etiology. Dis Aquat Org 23:115-126

Hasson KW, Lightner DV, Mari J, Bonami JR and others (1999a) The geographic distribution of Taura syndrome virus (TSV) in the Americas: determination by histopathology and in situ hybridization using TSV-specific cDNA probes. Aquaculture 171:13-26

Hasson KW, Lightner DV, Mohney LL, Redman RM, Poulos BT, White BM (1999b) Taura syndrome virus (TSV) lesion development and the disease cycle in the Pacific white

Editorial responsibility: Ken Hasson,

College Station, Texas, USA shrimp Penaeus vannamei. Dis Aquat Org 36:81-93

Hasson KW, Lightner DV, Mohney LL, Redman RM, White BM (1999c) Role of lymphoid organ spheroids in chronic Taura syndrome virus (TSV) infections in Penaeus vannamei. Dis Aquat Org 38:93-105

Jimenez R (1992) Sindrome de Taura (Resumen). Acuac Ecuad 1992:1-16

Le Gall O, Christian P, Fauquet CM, King AM and others (2008) Picornavirales, a proposed order of positive-sense single-stranded RNA viruses with a pseudo-T $=3$ virion architecture. Arch Virol 153:715-727

Lotz JM, Flowers AM, Breland V (2003) A model of Taura syndrome virus (TSV) epidemics in Litopenaeus vannamei. J Invertebr Pathol 83:168-176

Lotz JM, Salazar Anton L, Soto MA (2005) Effect of chronic Taura syndrome virus infection on salinity tolerance of Litopenaeus vannamei. Dis Aquat Org 65:75-78

$>$ Lu Y, Wang SY, Lotz JM (2004) The use of differential display to isolate viral genomic sequence for rapid development of PCR-based detection methods. A test case using Taura syndrome virus. J Virol Methods 121:107-114

> Mari J, Poulos BT, Lightner DV, Bonami JR (2002) Shrimp Taura syndrome virus: genomic characterization and similarity with members of the genus Cricket paralysis-like viruses. J Gen Virol 83:915-926

Mayo MA, Ball LA (2006) ICTV in San Francisco: a report from the Plenary Session. Arch Virol 151:413-422

Moss SM, Doyle RW, Lightner DV (2005) Breeding shrimp for disease resistance: challenges and opportunities for improvement. In: Walker PJ, Lester RG, Bondad-Reantaso MG (eds) Diseases in Asian aquaculture, Vol 5. Fish Health Section, Asian Fisheries Society, Manila, p 379-393

Poulos BT, Noble BW, Lightner DV (2008) Comparison of Taura syndrome virus (TSV) detection methods during chronic-phase infection in Penaeus vannamei. Dis Aquat Org 82:179-185

Srisuvan T, Noble BL, Schofield PJ, Lightner DV (2006) Comparison of four Taura syndrome virus (TSV) isolates in oral challenge studies with Litopenaeus vannamei unselected or selected for resistance to TSV. Dis Aquat Org 71:1-10

Stuck KC, Stuck LM, Overstreet RM, Wang SY (1996) Relationship between BP (Baculovirus penaei) infection and energy reserves in larval and postlarval Pacific white shrimp Penaeus vannamei. Dis Aquat Org 24:191-198

- Tsai MF, Kou GH, Liu HC, Liu KF and others (1999) Longterm presence of white spot syndrome virus (WSSV) in a cultivated shrimp population without disease outbreaks. Dis Aquat Org 38:107-114

Tu C, Huang HT, Chuang SH, Hsu JP and others (1999) Taura syndrome in Pacific white shrimp Penaeus vannamei cultured in Taiwan. Dis Aquat Org 38:159-161

Yu C, Song Y (2000) Outbreaks of Taura syndrome in Pacific white shrimp (Penaeus vannamei) cultured in Taiwan. Fish Pathol 35:21-24

Submitted: September 16, 2009; Accepted: June 22, 2010

Proofs received from author(s): July 24, 2010 